\title{
RESGATE DA VIDA MONÁSTICA: DA EXEMPLARIDADE À REGRA
}

\author{
"Sete vezes ao dia eu te louvo!" \\ São Bento
}

Ana Maria Coutinho ${ }^{1}$

Matheus Henrique Silva de Rezende ${ }^{2}$

RESUMO: A discussão aqui proposta resgata a exemplaridade da vida de alguns santos, destacando seus testemunhos de vida, motivados pelo abandono de tudo em prol do Reino de Deus, contribuindo para a formação da vida monástica no oriente e ocidente medieval, num contexto de desolação com a crise de Império Romano. E, ainda, ressalta a expansão do cristianismo e a evangelização dos povos pagãos como medida de fortalecimento da Igreja.

Palavras-chave: Pagãos. Monges. Regra. Evangelização. Igreja.

ABSTRACT: The discussion here proposed intends to bring up the examplarity of saints lives, highlighting their life references, motivated by living it all behind in order to dedicate themselves to God, contributing to monastic life formation back in both East and medieval West, in a context of extreme desolation caused by the major crisis in the Roman Empire. And yet, it will present christianity's expansion and pagan people evangelization as a strengthening measure from the Church.

Keywords: Pagans. Monks. Rule. Evangelization. Church.

O presente texto tem como objetivo resgatar alguns testemunhos de vida que contribuíram para a construção do monasticismo no oriente e ocidente medieval, que foi importante para a expansão da evangelização de povos pagãos. No contexto de crise

\footnotetext{
${ }^{\text {I }}$ Mestre e Professora de História PUC-Minas. E- mail: anacoutinhopuc@gmail.com.

${ }^{2}$ Graduando da PUC-Minas.
} 
do Império Romano, a Igreja saiu fortalecida e contribuiu para a uniformização da regra monástica, através do papa Gregório I, o Grande.

As palavras monasticismo, monarquismo e monástica derivam da palavra grega monachos que significa pessoa solitária, cuja prática de vida é abdicar-se do convívio e dos objetivos dos demais em detrimento de uma vida de recolhimento, de silêncio, de meditação e oração. Entretanto, esta vida de silêncio, de abstinência, de oração nem sempre foi tranquila e harmônica. Existiram excessos, desregramentos, indisciplinas, euforias, loucuras. Mas aqueles monges que alcançaram um lugar de destaque no decorrer da história medieval deram testemunho de vida com atitudes de fé, de espiritualidade e de plenitude. E, chegaram até nós porque alimentaram e alicerçaram a Igreja sempre ameaçada pela corrupção, pela vaidade, por ideias e ideais que ora se contradizem, ora recuam na defesa da fé, ora avançam e às vezes sequer percebem e/ou respondem às necessidades dos fiéis. De toda forma o movimento monástico assegura, alimenta, enriquece e fortalece a vida da Igreja.

No início do cristianismo, esses monges deixaram suas vidas e separaram-se do convívio com a comunidade, com o objetivo de viver uma vida de oração e de serviço a Deus. Faz-se aqui uma distinção entre os monges: monges eremitas, completamente isolados, vivendo de jejum e em oração, e os cenobitas, que observavam o celibato, a pobreza, juntavam os seus bens em comum, passavam o tempo em oração e em contemplação.

Naquele momento se inquiria se o crescimento do cristianismo e a crise do Império Romano teriam favorecido o crescimento do movimento monástico. E, ainda hoje, a pergunta nos acompanha na constatação de inúmeras ordens monásticas criadas ao longo da história e que perduram até os nossos dias. Quais são as motivações para estas pessoas se refugiarem do mundo?

Com certeza a crise que se alastrou no Império Romano trouxe preocupações, inseguranças, empobrecimento. $\mathrm{O}$ retorno parcial à economia natural com a população diminuída principalmente nas cidades, a exploração e pauperização das massas populares devido à alta da inflação e o aumento de encargos fiscais transformavam os 
pequenos agricultores em escravos ou colonos. Também contribuíram disputas internas entre as diversas categorias e camadas intermédias da classe dominante, a falta de proteção nas fronteiras do império e as incursões dos Bárbaros. Além disso, acredita-se que os discursos veiculados pelos cristãos naquele momento tenham sido espelhados em Jesus para chamar as pessoas a seguirem o seu caminho, sendo firmes e destemidas, demonstrando nas suas atitudes: virtude, moderação dos instintos e dos impulsos humanos. As pessoas deveriam ser cuidadosas, moderadas nos seus hábitos e despojadas das coisas materiais, vivendo exclusivamente ao serviço da caridade, com prudência e paciência.

É muito provável que todos esses aspectos tenham corroborado para que as pessoas buscassem uma outra possibilidade de vida, um outro modo de se portar diante do mundo. Daí destacarmos as pessoas de Santo Antão, São Pacômio e São Basílio que marcaram a história da vida monástica. Mas é bom que indaguemos quem foram estes santos homens e de que maneira podemos observar os seus ensinamentos e os movimentos na construção da Igreja Católica. Faltam documentos acerca de cada um deles, e as mesmas narrativas são repetidas nos textos e livros da história da Igreja a respeito da vida monástica. Daí se perguntar qual a importância de tal estudo? Um dos motivos deste estudo são as possíveis releituras dos acontecimentos que contribuem para a formação da mentalidade do ocidente medieval.

Santo Antão nasceu por volta de 250, como Antônio. Filho de cristãos de muitas posses que viviam na cidade de Mênfis, no Egito. Conta-se que teria recebido uma graça e, como gesto de desapego e anúncio de encontro com Deus, vende todos os bens, as suas terras, e distribui para as pessoas necessitadas de sua vila natal. $O$ patriarca de Alexandria, Santo Atanásio, é o narrador da vida de Antônio e conta-se que ele não se dirigiu imediatamente para o deserto, primeiramente foi fazer os primeiros exercícios de aprendizado em uma comunidade para internalizar como deveria ser a distribuição do seu tempo para a leitura da bíblia e para o trabalho manual.

[...]Indo à igreja, como era o seu costume, ele pensava em si mesmo, meditava, caminhando, como os Apóstolos haviam deixado tudo para seguir Cristo, como, segundo os Atos dos Apóstolos, os fiéis vendiam seus bens e dispunham do que 
apuravam, pondo-o à disposição dos Apóstolos ou deixando-o para os necessitados; (...) $[\ldots]$. (Santo Atanásio apud Comby, 1993, p.86.)

Depois deste tempo sob a autoridade de um "velho", Antônio dirige-se para um túmulo escavado em uma rocha, seguindo posteriormente para um castelo abandonado, onde teria vivido por uns vinte anos, mas não totalmente isolado do mundo e da convivência com as pessoas. A fama de Antônio começa a circular e os discípulos vão chegando. Eles vinham de longe para escutarem e pedirem os seus conselhos. Conta-se que ele não teria propriamente criado um convento, e que cada um de seus discípulos criou a sua própria célula, reunindo-se para a oração e a eucaristia. No ano de 3II, ele vai para Alexandria, estabelecendo-se depois no monte Quelzoûm, um oásis. Morreu com Ios anos.

Se até os nossos dias falamos de Santo Antão foi porque deixou influências através de seu exemplo de vida e do espírito excepcional, orientando toda a vida monacal desde então. Por conseguinte, se Santo Antão foi um precursor da experiência de vida eremítica, foi Pacômio, o Pai dos cenobitas, que estabeleceu as regras da vida em comum. Enquanto a vida de Santo Antão é inspiradora do ponto de vista espiritual, Pacômio é alguém que se debruça sobre a organização da vida monástica. Porém, a regra se perdeu e pouco se sabe a respeito dela. Segundo Murray, "as primeiras linhas da regra elucidam-nos:

Em nome da Santa Trindade.

Regulamento que o anjo do senhor recomenda ao Abade Pacômio.

[...] Quando vivia numa caverna, o anjo do Senhor apareceu-lhe e disse-lhe: (...) sai, reúne os jovens e vive com eles; instrói-os segundo o regulamento que te vou dar. E entregou uma tabuinha de bronze onde se encontravam escritas as seguintes palavras...

Segue-se a enumeração dos quinze primeiros preceitos: E então o grande Pacômio respondeu ao anjo: "é pouca oração".

O anjo disse-lhe: "Recomendei-te isso para que os jovens possam praticar este regulamento sem dificuldade, pois que os homens já feitos não precisam de regulamento; efetivamente, passaram a vida na contemplação do Senhor. Faço-te regulamentos para aqueles que estão privados de direção, a fim de que, como servidores, eles possam fazer o que lhes é ordenado e venham assistir aos ofícios de livre vontade e de rosto alegre [...] (Murray:1986, p.25-26)

Pacômio nasceu perto de Esneh, no Egito, em 290. Morreu em Tabennisi, em 346. Conta-se que foi soldado do exército imperial e, dispensado, tornou-se cristão. 
Colocou-se sob a subordinação de um anacoreta, Palemon. Anacoreta significa um eremita, aquele que vive solitariamente. À medida que foi organizando os conventos segundo princípios de vida comum, criou mais de nove casas, sendo duas delas para mulheres, constituindo os primeiros conventos femininos do Egito. De toda maneira São Basílio e São Bento foram sucessores deles.

De Basílio conta-se que pertencia a antiga família cristã, rica e de posição social. Foi educado em escolas de Cesaréia, Constantinopla e Atenas. Visitou diversos mosteiros do oriente, até se estabelecer em Anesos, às margens do rio Íris. Viveu por cinco anos em comunidade, mas é considerado o precursor do monasticismo no Oriente. Ele se tornou bispo da Igreja Ortodoxa, em 370, tendo exercido grande influência sobre ela. Uma das grandes obras de Basílio foi a construção de um estabelecimento denominado "comunidade” que incluía moradias, uma igreja, hospital com pessoas capacitadas para auxiliar os doentes, além de uma hospedaria para receber os viajantes, prática recorrente nos mosteiros ao longo da Idade Média. "Muito do que se conhece da vida de São Basílio foi tirado de suas cartas e de seus sermões, que formam um quadro vívido de sua personalidade multifacetada e de suas várias atividades.” (ATTWATER:1983, p.47)

Neste contexto avistamos uma Igreja ainda por se constituir e baseada na estrutura do Império Romano, modelo de instituição vigente e a ser seguido. A Igreja, mesmo na sua fragilidade e sem poder contar com o poder do imperador, ficará assustada e ameaçada com a proliferação dos mosteiros, pela força e manifestação de fé dessas comunidades monásticas. O retrato observado é de uma igreja ritualística em paralelo à vida monástica reluzente de oração e de espiritualidade. Consequentemente, a vida destes monges será um propulsor no processo de evangelização e de espiritualidade no ocidente medieval.

Um dos motivadores presentes no cenário da crise de Roma, como já se disse, é o movimento dos bárbaros, mas em que medida eles irão se adequar ao território por meio da cristianização? De alguma maneira a presença dos bárbaros no interior do ocidente aumenta o desejo de se instalar no território, aceitando ou não os ideais 
cristãos. Talvez seja esse aspecto fator de diferenciação entre os bárbaros no processo de evangelização e conversão. Diria ainda acerca do entendimento e compreensão dos símbolos, dos rituais e de crenças do cristianismo, que esses diversos povos irão articular manifestações próprias do paganismo com expressões cristãs. Em contrapartida, não se pode afirmar que o paganismo tenha sido extirpado quando a Igreja se institucionaliza, haja vista que ao longo da história temos presente traços e rituais pagãos no interior de manifestações cristãs. A sobrevivência de um e de outro se constituiu no seio da sociedade ocidental porque mantiveram em certa medida as articulações e contradições: rito pagão e rito cristão.

Uma pessoa importante a ser destacada é Martinho de Tours. Nascido na Panônia, Hungria, em 315, e morto em Candes, perto de Tours. Foi soldado, que deixou as armas para ser um soldado de Cristo. A sua história de vida é narrada por São Sulpício.

(...) Martinho é atraído pelo cristianismo sob a sua forma mais exigente, a do ascetismo. Adquire o hábito de dar esmolas. Um dia, em pleno inverno, na porta de Amiens, onde se encontra aquartelado, encontra um mendigo nu e reparte com ele seu casaco. Na noite seguinte, tem um sonho em que Cristo veste a metade do casaco que ele dera ao mendigo. (Le Goff: 2013.p.22)

Martinho contribuiu para a conversão de muitos habitantes que viviam no espaço rural e que serão os últimos a aderirem ao cristianismo. Juntamente com os monges, visitava as aldeias pagãs, pregando o evangelho, construía igrejas e fundava mosteiros, transformando os monges como sinal de simplicidade e de caridade cristã, e todo o povo se convertia. Ainda, segundo São Sulpício, Martinho teria recebido dons místicos e a sua vida era devotada aos pobres e doentes que tanto amparava. Uma das suas preocupações e empenho foi lutar contra o paganismo e em favor do cristianismo. São Sulpício é o grande revelador de São Martinho devido, principalmente, a uma biografia e três longas cartas escritas sobre ele. E, ainda, foi o grande santo não martirizado a ser venerado pelas pessoas. Diversas igrejas foram construídas ao longo da Europa ocidental como testemunho da sua vida e de seus milagres. Segundo Le Goff, “[n]o fim da Idade Média, três patronos dominam de longe todos os outros na Europa: Pedro, Maria e Martinho.” (Le Goff: 2013, p.24) 
Como sabido, no século IV, com Teodósio, é que se ampliam as regalias do estatuto da Igreja, convertendo o Cristianismo em religião oficial do Estado e, ainda, proibindo-se o paganismo. E, com Leão $\mathrm{V}$, temos a formulação da justificativa de que o primeiro bispo de Roma seria alçado à condição de Papa. Nem sempre esta polêmica se deu de maneira efetiva, até porque Gelásio, em 492-496, defendeu a ideia da existência de dois poderes: os leigos governariam os corpos e os eclesiásticos governariam as almas.

$\mathrm{Na}$ tentativa de fortalecimento da cristianização, os mosteiros se multiplicaram a partir da experiência de São Bento de Núrsia. Nesse sentido, a ordem monástica de São Bento virá responder às necessidades daquela comunidade cristã que se ergue, dentro de uma Igreja que acaba de ser institucionalizada efetivamente, apesar das contradições e ambiguidades inerentes a toda e qualquer instituição e as relações de poder estabelecidas. Mas terá um efeito maravilhoso, perdurando ainda nos nossos dias e simbolizando vida de fé e de oração. E, quem era Bento, denominado pela Igreja como sendo o patriarca dos monges ocidentais? Segundo Le Goff: "Sabe-se pouca coisa sobre São Bento, a não ser aquilo que por conta própria nos legou o Papa Gregório, o Grande, que lhe dedicou o livro II de seus Dialogues (...)” (LE GOFF: 2013, p.29)

\footnotetext{
Assim, é sabido que teria nascido em Núrsia, na Úmbria, filho de família de posses e, teria recebido instrução de conhecimentos da cultura antiga. Mas será a sua experiência em Subiaco, dedicando-se a um ascetismo rigoroso, que fará com que seu prestígio se esparramasse por entre as famílias que enviam os seus filhos como oblatos e futuramente, se tornam os seus discípulos. Mas é a regra criada por Bento que o torna presente nos nossos tempos: "ora et labora”, ore e trabalhe. "O ócio é inimigo da alma. Assim, os irmãos devem estar ocupados, em tempos determinados, no trabalho manual e em horas determinadas também, à leitura divina. (FROHLICH:1987, p.46.)
}

Os monges trabalhavam na biblioteca, nos campos e nas oficinas, com o intuito de servir também de exemplo aos camponeses da região circunvizinha. Além disso, realizavam obras sociais, dando hospedagem aos peregrinos, distribuindo esmolas aos necessitados. Mas é nas bibliotecas que serão eficientes ao preservar e copiar os textos dos autores clássicos e traduzi-los. 
Revista Ibero- Americana de Humanidades, Ciências e Educação- REASE

open 2 access

Figura I - Ilustração São Bento de Núrsia dá a regra beneditina aos monges que se aproximam e carregam um livro.

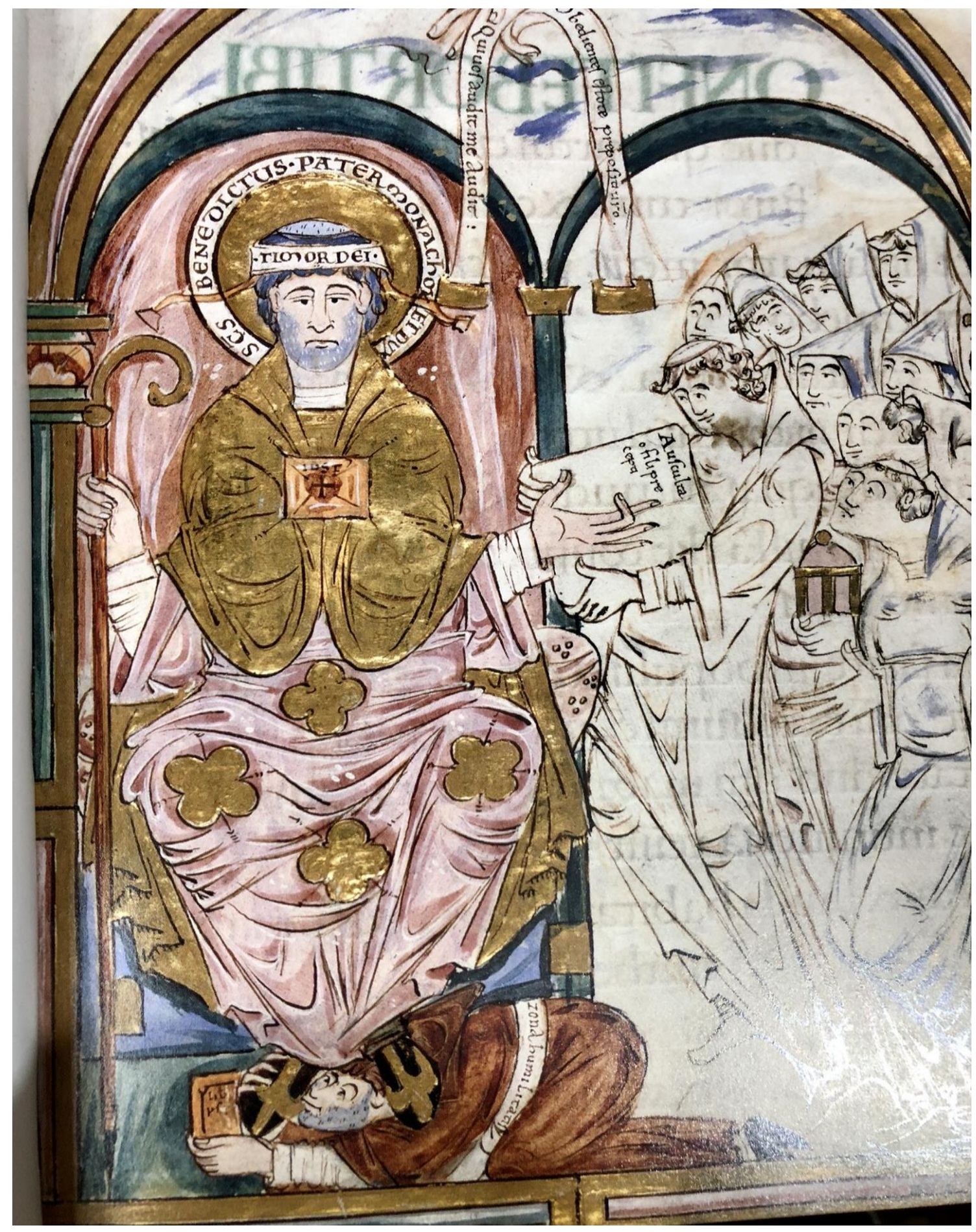


De acordo com Le Goff: “A regra beneditina deve seu sucesso, em ampla medida, às suas qualidades de equilíbrio e de medida". (LE GOFF: 2013, p.29)

Para Bento, a vida religiosa constitui uma escola do "serviço do Senhor" e a respeito do trabalho afirma:

A preguiça é inimiga da alma. Por isto em horas fixas os irmãos devem estar ocupados em trabalhos manuais, e em outras horas fixas em leituras sagradas. Portanto, pensamos que essas duas coisas devem ser ordenadas da seguinte maneira: da Páscoa até as Calendas de outubro (primeiro de outubro) até a prima farão todo o trabalho que for necessário até a hora quarta. Da quarta hora até a sexta hora devem aplicar-se à leitura. (...). (Bettenson: 1983, p. 169)

E, ainda, segundo Le Goff, o grande impulsionador da regra de Bento foi o Papa Gregório I, o Grande, que formalizará o processo de uniformização da vida monástica. Gregório nasceu na Roma Antiga, passou a juventude em um palácio no Monte Célio, herdou uma grande fortuna com a morte do pai. Aos 30 anos de idade tornou-se prefeito da cidade de Roma. Após alguns anos, deixou a cidade e se fixou no palácio da família em Clivus Scauri, defronte ao Palatino, para uma vida reservada, de silêncio monástico. Após alguns anos foi encarregado do papa Pelágio II, junto à corte Bizantina, cumprindo funções políticas e eclesiásticas.

Dentro da História da Igreja, o Papa Gregório foi eleito no ano de 590, em momento de peste, fome e perigo dos lombardos, acrescido da falta de apoio do imperador de Bizâncio. Dentre as atividades a desenvolver, se ateve à atividade caritativa com a renda dos ricos patrimônios papais na Sicília. Afirmava: "Eu frequentemente encarreguei vocês... a agirem como meus representantes ... para aliviar o sofrimento dos pobres... (...) Eu ocupo o posto de zelador da propriedade dos pobres...."

Gregório é apresentado realmente como destaque porque se responsabilizou por levar à frente a obra missionária, desligando a Sé de Pedro do Império, o que significa uma definição clara dos poderes que, até então, balançavam-se numa linha tênue, ora o poder da Igreja se impunha, ora o poder do Imperador. O seu tempo, foi marcado pela prudência econômica e esforçou-se por suprimir a simonia e a concubinagem do 
clero. Restabeleceu a disciplina nos mosteiros latinos e regulamentou suas relações com o clero secular e o papa. E, de certa forma, aperfeiçoou o cânone da missa, mas, erroneamente, é tido como o criador do canto gregoriano.

Além disso, ele suprimiu a exploração nos Estados Papais, adiantou dinheiro a lavradores arrendatários sem cobrar juros, mas cobrava prontamente as receitas devidas. Difundiu o evangelho pela Europa, submeteu os bispos rebeldes da Lombardia, restaurou o catolicismo ortodoxo na África e acolheu a conversão da Espanha com o rei Recaredo. Consequentemente será sempre lembrado pelo papel fundamental que teve na história da Igreja, por todas as suas obras e, mais, pela atribuição dada a Santo Agostinho e seus companheiros, de irem para a Britânia, atual Bretanha, evangelizar os pagãos.

Figura 2- Ilustração Papa Gregório, o grande, em seu gabinete e três monges copistas, (...)

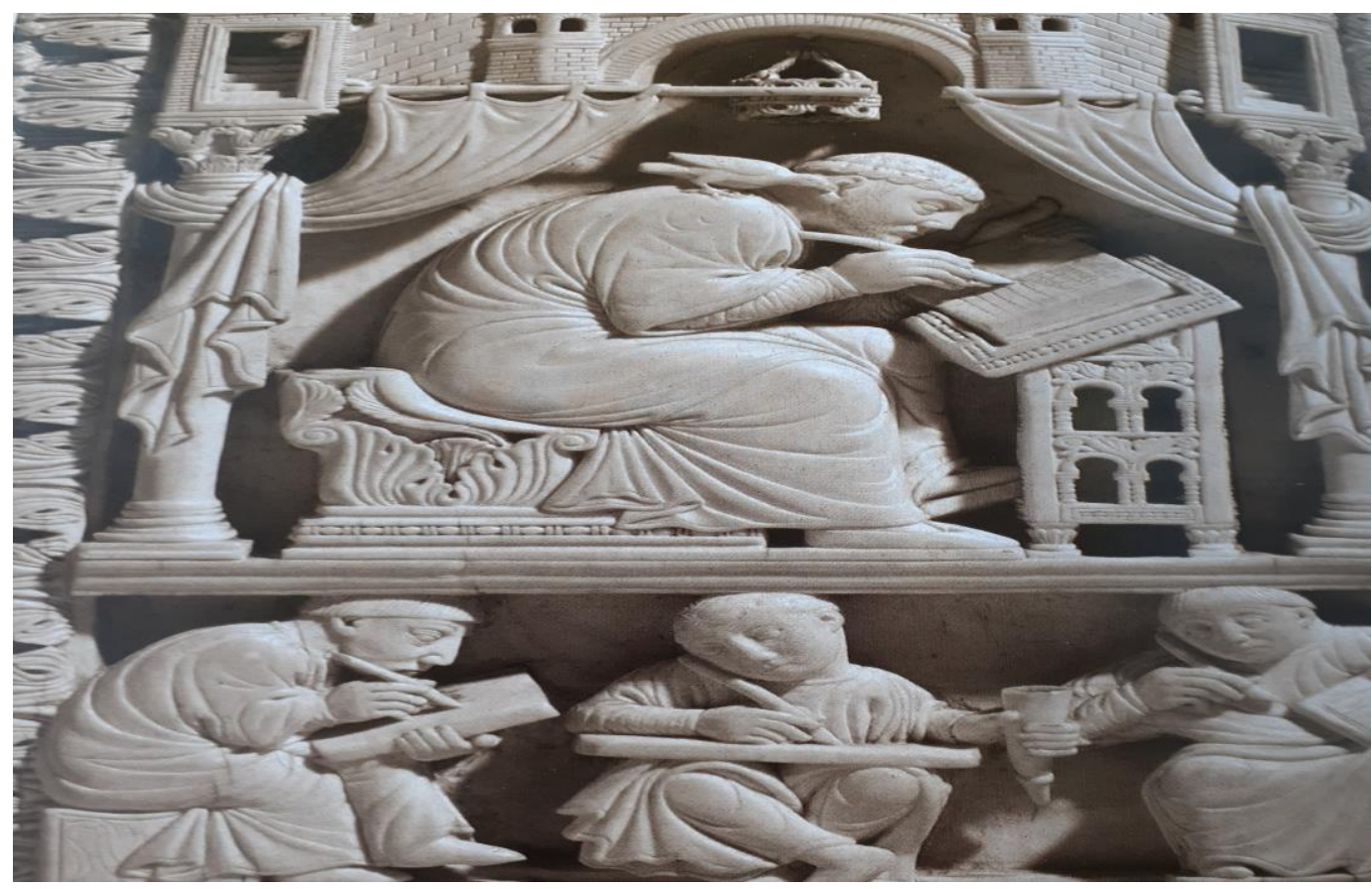

\section{Monasticismo nas Ilhas Britânicas}

O pontífice Gregório I realizou esse movimento de reconquista na região da Britânia, atual Inglaterra, devido ao recrudescimento do cristianismo nessa que outrora fora uma das províncias imperiais. A necessidade de enviar missionários às 
terras insulares pagãs do Norte europeu manifestou-se na mente do Papa Gregório em 595, quando o mesmo vê um grupo de anglos que haviam sido trazidos ao continente como escravos (BROWN, 1999). Em uma carta ao Patriarca de Alexandria, três anos após esse acontecimento, Gregório relata o processo:

Como o povo dos Ingleses, colocado num canto do mundo, se manteve até hoje na falsa adoração de animais e pedras, resolvi... enviar... um monge do meu mosteiro para pregar a este povo... E mesmo agora recebi cartas... [que dizem como] ele e os que o acompanharam conseguiram tais milagres que os próprios milagres dos apóstolos parecem reviver nos indícios que nos enviam. (BROWN: 1999, p.163)

O declínio da fé Cristã e o avanço do paganismo deveram-se à conquista anglosaxã das terras que haviam pertencido a "reinos" bretões - estes já apresentavam um cristianismo avançado dentro de suas populações - que se formaram após a saída das legiões romanas durante a crise do séc. V. No início do séc. VII, os reinos anglo-saxões já haviam se estabelecido, legando aos bretões as terras correspondentes ao atual País de Gales no Oeste e aos pictos ao Norte, no que corresponde à atual Escócia.

Por outro lado, na ilha vizinha, a Irlanda, ocorria o movimento contrário, o cristianismo avançava rapidamente entre a população. Essa façanha é obra de um bretão, São Patrício, que em sua juventude havia sido escravizado por irlandeses e, alguns anos após sua fuga, ele retorna para converter seus algozes à fé em Cristo. Segundo o mesmo, sua captura havia sido um castigo divino, devido ao fato de seu afastamento e o não cumprimento dos desígnios e preceitos de Deus.

I) [...] Eu ignorava o verdadeiro Deus e junto com milhares de pessoas fui capturado e conduzido ao cativeiro na Irlanda segundo o nosso merecimento, por afastarmos-nos bastante de Deus, não guardamos os seus preceitos, nem sermos obedientes aos nossos sacerdotes, que nos exortavam a respeito da nossa salvação. E o Senhor lançou sobre nós a violência de sua cólera e nos dispersou entre vários povos até os confins da terra, onde agora na minha pequenez, me encontro entre estrangeiros. (PATRÍCIO: 2007, p.iro)

Para Patrício, sua conversão ocorre no contexto de sua escravatura, acaba por se tornar um homem bastante devoto. Em sua concepção, Deus retribui sua fé com a possibilidade de fuga:

16) Mas, depois que alcancei a Irlanda e que eu passei a apascentar o rebanho cotidianamente e orava várias vezes ao dia, mais e mais o amor de Deus e o meu temor e fé por ele cresceram e o meu espírito tocado de tal maneira, que em dia cheguei a contar mais de cem orações e de noite quantidade semelhante, e ainda ficava nas 
florestas e nas montanhas, acordava antes da luz do dia para orar na neve, no gelo e na chuva, e nenhum mal eu sentia e nenhuma preguiça estava em mim, como percebo agora, porque o espírito ardia dentro de mim. 17) E lá naturalmente uma noite no meu sono eu ouvi uma voz dizendo para mim: "Fazes bem em jejuar, pois brevemente partirás para a tua pátria" e novamente muito pouco tempo depois ouvi uma voz me dizendo: "Eis que teu navio está pronto" e não era em um lugar perto não, pelo contrário, estava a duzentas milhas de distância onde eu nunca havia estado e não havia ninguém conhecido. Então pouco tempo depois eu me coloquei em fuga e abandonei o homem com quem estivera seis anos e avancei na virtude de Deus, que dirigiu meu caminho para o bem e eu nada temi até que alcancei aquele navio. (PATRÍCIO: 2007, II3-II4)

De volta à Britânia, Patrício começa a sonhar com o chamado divino para regressar à terra onde fora escravo e converter seus algozes. Nos sonhos, vozes diziam: “Nós te rogamos, santo jovem, venha e caminhe novamente entre nós" (PATRÍCIO, 2007, p.II6). Depois de ordenado bispo, decide retornar à Irlanda para iniciar sua missão evangelizadora.

Nessa ilha o cristianismo irá se desenvolver de uma forma singular, diversamente do continente, estruturado em torno dos Bispos. Na Irlanda prevalecerá a figura dos_Abades dos mosteiros em relação ao bispado; contudo, essa forma distinta de organização não significou um afastamento da Igreja Irlandesa da Sé Romana, ao contrário, os cristãos irlandeses reconheciam a autoridade na figura do Sumo Pontífice, e vice-versa. A Igreja de Roma reconhecia o modelo de estrutura adotado na ilha e apenas fazia ressalvas à data escolhida para a realização da Páscoa, como afirma Schorer (1954, p. 282)

Em Roma, conheciam a organização eclesiástica da Irlanda, mas não a reprimiam. Beda se refere às cartas (629-640) que os Papas Honório e João IV escreveram aos escotos, exortando-os a que fixassem a Páscoa corretamente, sem se referirem, entretanto, à organização eclesiástica.

Apesar da discrepância no modelo organizacional, a Igreja Irlandesa e a do continente apresentavam uma semelhança em sua estruturação. Ambas eram baseadas no molde em que se constituíam as sociedades que alicerçavam seu surgimento. Se, por um lado, nas antigas províncias imperiais a Igreja tomava como base os bispados que correspondiam às antigas demarcações romanas, na Irlanda, por outro lado, a Igreja se baseava na organização tribal, como propõe Maria Thereza Schorer (1954, p.28I): "Pode-se dizer que o mosteiro, logo depois da conversão, confunde-se com o 
clã". Isso se deve ao fato de que a Hibernia - nome latino da Irlanda - nunca estivera confinada nas fronteiras imperiais e, apesar do contato que mantinham com Roma, isso não significou uma alteração da estrutura social. Quando um chefe se convertia, era feito um pedido de algumas terras para a construção de um mosteiro e, como propõe Schorer, "o abade dirige a "província", cujos limites parecem coincidir com os do clã" (SCHORER: 1954, p.28I).

Para os cristãos, o martírio era uma forma grandiosa de expor a potência de sua fé, tanto para os pagãos, quanto para os outros cristãos. Em relação aos mártires, Peter Brown afirma: "aqueles que morreram por Cristo tornaram o seu Deus extraordinariamente presente para os outros crentes. Mesmo quando se encontrava preso, o mártir em potencial era motivo de uma imensa alegria para a comunidade cristã" (BROWN: 1999, p.46). Para os irlandeses, o modo de elevar a fé se apresentou de outra forma, visto que não ocorriam grandes martírios em terras irlandesas e os monges buscavam outra forma de sacrifício por Cristo. Para Schorer, os religiosos irlandeses praticam o que a autora chama de "martírio branco", isso ocorre quando um irlandês escolhia deixar sua terra natal e ir viver o resto de seus dias como um estrangeiro.

Para eles, isso nada mais era que um meio de mortificação, e certamente o mais rigoroso para eles que tanto amavam sua terra. [...] "o martírio branco é aquele em que um homem se afasta, por amor a Deus de tudo de ele ama, apesar de sofrer jejum e trabalho com isso". Os monges irlandeses sofreram, portanto, "o martírio branco". Morrer no exílio, com uma terra estranha para sepultura era para o irlandês a maior das abnegações e a coroa de toda a vida religiosa. (SCHORER: 1954, p.294)

O avanço do monasticismo irlandês para fora de sua ilha teve como protagonista São Columba. O santo irlandês vivia em um contexto de expansão da área de influência do clã a que pertencia, os O' Neill. Em um conflito de que participou, foi acusado de derramar sangue, acabou sendo exilado por ser um clérigo e estabeleceuse, em 565, na ilha de Iona. O mosteiro criado pelo santo terá um papel de destaque na Igreja Irlandesa, para Brown (I999, p.216):

Columba tinha conseguido criar um império espiritual no Norte que se assemelhava ao extenso reino dos outros O' Neill. Iona foi o vértice de uma pirâmide de mosteiros leais, que se estendiam entre o sul da Irlanda e as Hébridas. Depois de 635, os monges 
de Iona restabeleceram o cristianismo na Nortúmbria. Lindsfarne, ainda hoje chamada "Ilha Sagrada", transformou-se na Iona dos saxões do Norte. Ligado de perto a duas das mais duradouras hegemonias das Ilhas Britânicas: os O' Neill da Irlanda e os reis da Nortúmbria, Iona passou a dominar o mundo celta a partir do seu ponto mais ao Norte. Foi o início de uma nova era do cristianismo da Irlanda.

Esse meio monástico irlandês produziu influências que vão cruzar o canal da mancha e chegar ao continente. São Columbano, um contemporâneo do Papa Gregório I, chegou à Gália em 590, com alguns discípulos. O monge irlandês trouxe consigo uma inovação que introduziu na região, a que denominou de medicamenta paenitentiae, e a dirigiu principalmente à corte, pois concebia que eram os reis e guerreiros que mais necessitavam de terem suas almas curadas através da penitência (BROWN, 1999). Isto posto, qual era a diferença da penitência nas épocas anteriores a Columbano e a que foi introduzida pelo santo na Gália? Esclarece Peter Brown:

Na Igreja Primitiva, a reparação dos pecados fora uma experiência dramática de grupo. Eram os membros do "povo de Deus" que, em conjunto, excluíam os pecadores mais notórios do seu grupo, permitindo-lhes continuar nas franjas da Igreja, numa categoria separada de "penitentes" e assegurando-lhes depois a "paz" da reconciliação através de uma cerimônia pública dirigida pelo bispo. [...] o cristianismo do mundo celta insular estava mais perto do oriental do que da poderosa devoção coletiva da Europa Continental. Leigo, monge ou clérigo, todos tendiam a procurar uma "alma amiga", o anmcharae de cada um, a fim de receberem a penitência de suas mãos. Mas faziam-no num ambiente diferente. No mundo celta, a "alma amiga" devia atuar não só como médico, mas também como juiz. (BROWN: 1999, p.174)

Conclui-se que o estudo do modelo cristão irlandês nos mostra como se deu a estruturação da fé em uma sociedade que não havia sido profundamente influenciada por Roma, com suas semelhanças e diferenças, proporcionando um olhar mais amplo do processo de cristianização do Ocidente. Mostra como a cultura de um povo isolado no período pôde chegar a outras localidades e influenciá-las profundamente, a exemplo do caso da penitência.

De todo modo, o processo de formação e crescimento da vida monástica se constituiu, sobretudo, pelo testemunho de vida e conversão de Antão, Pacômio e tantos outros. Concomitantemente ao crescimento do devotamento monástico, percebe-se a expansão do Cristianismo com a evangelização dos povos pagãos no território da Europa ocidental. E, o Papa Gregório, ele mesmo beneditino, será sempre lembrado pelo grande impulso dado à atividade missionária dos monges. Cumprindo 
o objetivo de fortalecer a Igreja, usará da regra de São Bento como o eixo uniformizador da vida monástica.

REFERÊNCIAS BIBLIOGRÁFICAS:

Fontes Primárias

-PATRÍCIO. Confissão. In: DOS SANTOS, Dominique Vieira Coelho. Os Livros das Cartas do Bispo São Patrício. Brathair, v. 7, n. I, p. 107-136, 2007.

- REGRA DE SÃO BENTO. BETTENSON, H. Documentos da Igreja Cristã. Tradução de Helmuth Alfredo Simon. Rio de Janeiro e São Paulo: JUERP/ASTE, 1983, 2 ed.p.16o-175.

Fontes Secundárias

-ATTWATER, Donald. Dicionário dos Santos. São Paulo: Círculo do Livro, 1983, p.47.

-BETTENSON, H. Documentos da Igreja Cristã. Tradução de Helmuth Alfredo Simon. Rio de Janeiro e São Paulo: JUERP/ASTE, 1983, 2 ed.p.i6o-179.

-BROWN, Peter. A Ascenção do Cristianismo no Ocidente. I. ed. Lisboa: Editorial Presença, 1999.

-COMBY, Jean. Para Ler a História da Igreja I - Das Origens ao século XV. São Paulo: Edições Loyola, 2012.

-FROHLICH, R. SÃO BENTO in: Curso Básico de História da Igreja. São Paulo, Paulinas, 1987, p.46.

-LE GOFF, Jacques. (org.) Homens e Mulheres da Idade Média. São Paulo: Estação Liberdade; (tradução Nícia Adan Bonatti) 2013, p.22; 29; 57)

-LE GOFF-SCHMITT, Jacques-Jean. Dicionário Temático do Ocidente Medieval; Coordenação da tradução Hilário Franco Júnior. Bauru: EDUSC; São Paulo: Imprensa Oficial do Estado, 2002.2v.

-MURRAY, Bruno. As Ordens Monásticas e religiosas. Portugal: Publicações EuropaAmérica,1986, p.25-26.

-PIERRARD, Pierre. História da Igreja. São Paulo: Edições Paulinas, 1982, p.45-6o.

-SCHORER, Maria Thereza. Alguns aspectos do monasticismo irlandês, através da "História Ecclesiástica Gentis Anglorum” do Venerável Beda. Revista de História, v. 8, n. 18, p. 273-302, 1954 .

Imagens:

Figura i e 2

LE GOFF, Jacques. (org.) Homens e Mulheres da Idade Média. São Paulo: Estação Liberdade; (tradução Nícia Adan Bonatti) 2013, p.31 e p.56 